Research article

Open Access

\title{
Analysis of skewed X-chromosome inactivation in females with rheumatoid arthritis and autoimmune thyroid diseases
}

\author{
Ghazi Chabchoub1', Elif $\mathrm{Uz}^{2}$, Abdellatif Maalej ${ }^{1}$, Chigdem A Mustafa ${ }^{2}$, Ahmed Rebai ${ }^{3}$, Mouna Mnif ${ }^{4}$, \\ Zouheir Bahloul ${ }^{5}$, Nadir R Farid6, Tayfun Ozcelik2,7 and Hammadi Ayadi1
}

\author{
1'Laboratoire de Génétique Moléculaire Humaine, Faculté de Médecine de Sfax, Avenue Majida Boulila, Sfax, 3029, Tunisie \\ ${ }^{2}$ Department of Molecular Biology and Genetics, Faculty of Science. Bilkent University, Ankara, 06800, Turkey \\ 3Unité de Bioinformatique, Centre de Biotechnologie de Sfax, Sfax, BP 3018, Tunisie \\ ${ }^{4}$ Service d'Endocrinologie, Centre Hospitalo-universitaire Hédi Chaker de Sfax. Rue El-Ferdaous, Sfax, 3029, Tunisie \\ ${ }^{5}$ Service de Médecine Interne, Centre Hospitalo-universitaire Hédi Chaker de Sfax. Rue El-Ferdaous, Sfax, 3029, Tunisie \\ 6 Osancor Biotech Inc, 31 Woodland Drive, Watford, Herts, WD17 3BY, UK \\ ${ }^{7}$ Institute for Materials Science and Nanotechnology (UNAM), Bilkent University, Ankara, 06800, Turkey \\ Corresponding author: Ghazi Chabchoub, ghazi.chabchoub@laposte.net
}

Received: 5 Nov 2008 Revisions requested: 12 Dec 2008 Revisions received: 22 Jun 2009 Accepted: 9 Jul 2009 Published: 9 Jul 2009

Arthritis Research \& Therapy 2009, 11:R106 (doi:10.1186/ar2759)

This article is online at: http://arthritis-research.com/content/11/4/R106

(c) 2009 Chabchoub et al.; licensee BioMed Central Ltd.

This is an open access article distributed under the terms of the Creative Commons Attribution License (http://creativecommons.org/licenses/by/2.0), which permits unrestricted use, distribution, and reproduction in any medium, provided the original work is properly cited.

\begin{abstract}
Introduction The majority of autoimmune diseases such as rheumatoid arthritis (RA) and autoimmune thyroid diseases (AITDs) are characterized by a striking female predominance superimposed on a predisposing genetic background. The role of extremely skewed $\mathrm{X}$-chromosome inactivation $(\mathrm{XCl})$ has been questioned in the pathogenesis of several autoimmune diseases.

Methods We examined XCl profiles of females affected with RA $(n=106)$, AITDs $(n=145)$ and age-matched healthy women ( $n$ $=257$ ). XCl analysis was performed by enzymatic digestion of DNA with a methylation sensitive enzyme (Hpall) followed by PCR of a polymorphic CAG repeat in the androgen receptor $(A R)$ gene. The $\mathrm{XCl}$ pattern was classified as skewed when $80 \%$ or more of the cells preferentially inactivated the same $\mathrm{X}$ chromosome.
\end{abstract}

Results Skewed XCl was observed in 26 of the 76 informative RA patients (34.2\%), 26 of the 100 informative AITDs patients (26\%), and 19 of the 170 informative controls $(11.2 \%)(P<$ $0.0001 ; P=0.0015$, respectively). More importantly, extremely skewed $\mathrm{XCl}$, defined as $>90 \%$ inactivation of one allele, was present in 17 RA patients (22.4\%), 14 AITDs patients (14.0\%), and in only seven controls $(4.1 \%, P<0.0001 ; P=0.0034$, respectively). Stratifying RA patients according to laboratory profiles (rheumatoid factor and anti-citrullinated protein antibodies), clinical manifestations (erosive disease and nodules) and the presence of others autoimmune diseases did not reveal any statistical significance $(P>0.05)$.

Conclusions These results suggest a possible role for $\mathrm{XCl}$ mosaicism in the pathogenesis of RA and AITDs and may in part explain the female preponderance of these diseases.

\section{Introduction}

It is postulated that the paternal and maternal antigens will be recognized by the immune system within the thymus, and $\mathrm{T}$ cells that have a high affinity for such antigens will be deleted by apoptosis [1-3]. The lack of exposure to a self-antigen in the thymus may lead to the presence of autoreactive $T$ cells and increase the risk of autoimmunity [4]. In female mammalian cells, one of the two X-chromosomes is inactivated in early embryonic life [5]. Thus, females are mosaics for two cell pop- ulations, cells with either the paternal or the maternal $X$ in the active form. X-chromosome choice is assumed to be random, and the result is generally $50 \%$ of cells expressing the paternal and the remaining 50\% expressing the maternal genes [6]. A skewed $\mathrm{X}$-chromosome inactivation $(\mathrm{XCl})$ is a deviation from this ratio and is arbitrarily defined, for example, as a pattern where $80 \%$ or more of the cells inactivate the same X-chromosome [7]. This deviation may be the result of chance or genetic factors involved in the $\mathrm{XCl}$ or a selection process [8]. The 
existence of $\mathrm{XCl}$ in females offers a potential mechanism where by $\mathrm{X}$-linked self-antigens may escape presentation in the thymus or in other peripheral sites that are involved in tolerance induction $[9,10]$. This has become an attractive candidate mechanism for breakdown of self-tolerance in autoimmune diseases. An association between skewed $\mathrm{XCl}$ and scleroderma was recently reported [11]. A higher frequency of a skewed XCl pattern was found in patients affected with autoimmune thyroid diseases (AITDs) compared with healthy controls, indicating that skewed $\mathrm{XCl}$ may be associated with a predisposing factor for the development of AITDs [12-14]. It was therefore of interest to study if there is an association between skewed $\mathrm{XCl}$ and rheumatoid arthritis (RA) as a non-organ-specific and AITDs as an organ-specific autoimmune disease. We investigated the peripheral blood $\mathrm{XCl}$ patterns of 106 females affected with RA, 145 females affected with AITDs and 257 controls in the Tunisian and Turkish populations. Extremely skewed $\mathrm{XCl}$ was found in the blood samples of female patients affected with RA and AITDs supporting the role of skewed $\mathrm{XCl}$ in female predisposition to autoimmune diseases.

\section{Materials and methods Patients and controls}

$R A$ sample

One hundred and six Tunisian women affected with RA were recruited into the study. All patients fulfilled the 1987 American College of Rheumatology criteria for RA [15]. A rheumatologist university fellow $(\mathrm{ZB})$ reviewed all clinical data. The mean age was $47.6 \pm 13.4$ (mean \pm standard deviation (SD)) years. The duration of the symptoms was $15 \pm 8.9$ years. The mean age of diagnostic was $40.3 \pm 12$ years. Among 106 RA patients, 65 were rheumatoid factor (RF) positive (61.3\%), 70 were anti-citrullinated protein/peptide antibodies (ACPA) positive $(66 \%), 15$ presented with nodules $(14.1 \%)$, and 70 presented with erosive disease (66\%). Fifteen patients had another accompanying autoimmune diseases such as Sjögren's syndrome, type 1 diabetes, or autoimmune thyroid diseases.

\section{AlTDs sample}

One hundred and forty-five Tunisian women affected with AITDs were included in the study. There were a total of 58 patients with Graves' disease (GD) and 87 patients with Hashimoto's thyroiditis (HT), which include 40 patients with the goitrous form. The mean age was $46.5 \pm 14.5$ years for AITDs patients (49.3 \pm 13 years in HT patients and $44.6 \pm 14$ years in GD patients). The duration of the symptoms was 7.5 \pm 4.6 years among the AITDs patients $(6.8 \pm 4.8$ years in HT patients and $7.2 \pm 4$ years in GD patients). The mean age of diagnosis was $37.9 \pm 15.1$ years. The diagnosis of GD was based on the presence of biochemical hyperthyroidism as indicated by a decrease of thyroid-stimulating hormone (TSH), an increase of T4 levels, and positive TSH receptor antibody, in association with diffuse goiter or the presence of exophthalmos. The diagnosis of HT was based on the presence of thyroid hormone replaced primary hypothyroidism, defined as a TSH level above the upper limits associated with positive titers of thyroid autoantibodies (anti-thyroglobulin and/or anti-thyroid peroxidase) and with or without a palpable goiter.

\section{Control group}

Caucasian females, comprised of 97 Tunisian and 160 Turkish healthy unrelated volunteers, served as controls in our studies. The mean ( \pm SD) age at analysis was $43.5 \pm 15.3$ years and $35 \pm 9.9$ years for Tunisian and Turkish controls, respectively. There was no clinical evidence or family history of autoimmune disease and inflammatory joint disease.

All individuals (patients and controls) provided informed consent. The ethics committee of the Centre Hospitalo-Universitaire Hédi Chaker de Sfax, Tunisie, and the Bilkent University, Ankara, Turkey approved the study protocol.

\section{Methods}

Autoantibodies analysis

In AITDs patients, thyroid autoantibodies (anti-thyroglobulin and anti-thyroid peroxydase) were measured by ELISA and indirect immunofluorescence using commercially available kits

Table 1

Proportion of RA and AITDs patients and controls with skewed X-chromosome inactivation

Number (\%) observed with skewed

\begin{tabular}{lccc}
\multicolumn{1}{c}{ Degree of skewing (\%) } & RA $(n=76)$ & AITDs $(n=100)$ & Control females $(n=170)$ \\
\hline $90+$ & $17(22.4)$ & $14(14)$ & $7(4.1)$ \\
80 to 89 & $9(11.8)$ & $12(12)$ & $12(7.1)$ \\
70 to 79 & $11(14.5)$ & $23(23)$ & $29(17.1)$ \\
60 to 69 & $28(36.8)$ & $22(22)$ & $36(21.2)$ \\
50 to 59 & $11(14.5)$ & $29(29)$ & $86(50.6)$
\end{tabular}

For comparison by chi-squared $P<0.0001$ and $P=0.0015(>80 \%$ skewing); $P<0.0001$ and $P=0.0034$ (90+\% skewing) for patients with rheumatoid arthritis (RA) and autoimmune thyroid diseases (AITDs), respectively. 


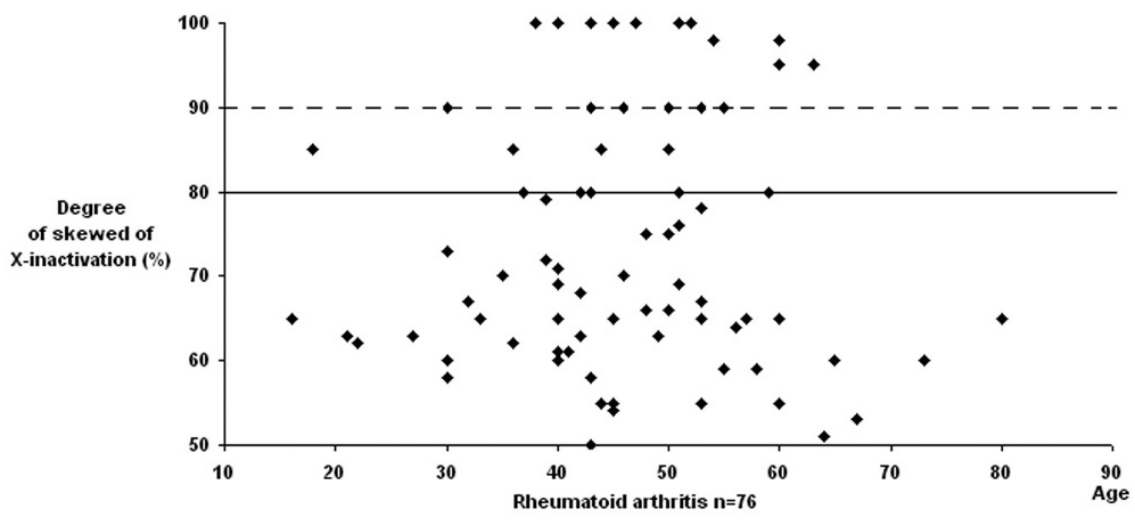

Distribution of X-chromosome inactivation patterns according to age in patients with rheumatoid arthritis.

(BINDAZYME ${ }^{\mathrm{TM}}$ Human EIA kits, Binding site Ltd, Birmingham, UK) with the respective normal ranges of 0 to 100 and 0 to 70 $\mathrm{IU} / \mathrm{mL}$.

The sera of RA patients obtained at the time of diagnosis were examined for RF by nephelometry and for ACPA by ELISA (second-generation test; Euro-Diagnostica, Arnhem, the Netherlands).

\section{$X$-chromosome inactivation study}

Genomic DNA was extracted from $10 \mathrm{ml}$ of peripheral blood lymphocyte of patients and controls using standard methods [16]. Genotyping of a polymorphic site in the androgen receptor $(A R)$ gene was performed and quantified to assess the $\mathrm{XCl}$ patterns as described [17]. The degree of skewing was estimated by an assay based on a methylation-sensitive Hpall restriction site located in exon 1 of the $A R$ gene. This site is methylated on the inactive $X$, and unmethylated on the active $\mathrm{X}$-chromosome. When the genomic DNA is cleaved with Hpall prior to $\mathrm{PCR}$, only the methylated $A R$ allele, which represents the inactive $\mathrm{X}$-chromosome, is amplified. A polymorphic CAG repeat located within the amplified region is used to distinguish between the two alleles. For each patient and control two separate PCRs, with or without Hpall treatment, were performed using the same set of primers. Densitometric analysis of the alleles was performed at least twice for each sample using the MultiAnalyst version 1.1 software (Bio-rad, Hercules, California, USA). A corrected ratio ( $\mathrm{CrR}$ ) was calculated by dividing the ratio of the predigested sample (upper/lower allele) by the ratio of the non-predigested sample for normalization of the ratios that were obtained from the densitometric analyses. The use of $\mathrm{CrR}$ compensates for preferential amplification of the shorter allele when the number of PCR cycles increases [18]. A skewed population is defined as a cell population with greater than $80 \%$ expression of one of the AR alleles. This corresponds to $\mathrm{CrR}$ values of less than 0.33 or more than three.

\section{Statistical methods}

The results from control and test groups in $\mathrm{XCl}$ studies were compared by chi-squared test with Yate's correction. Fisher's exact test was used when one cell had an expected count of

Figure 2

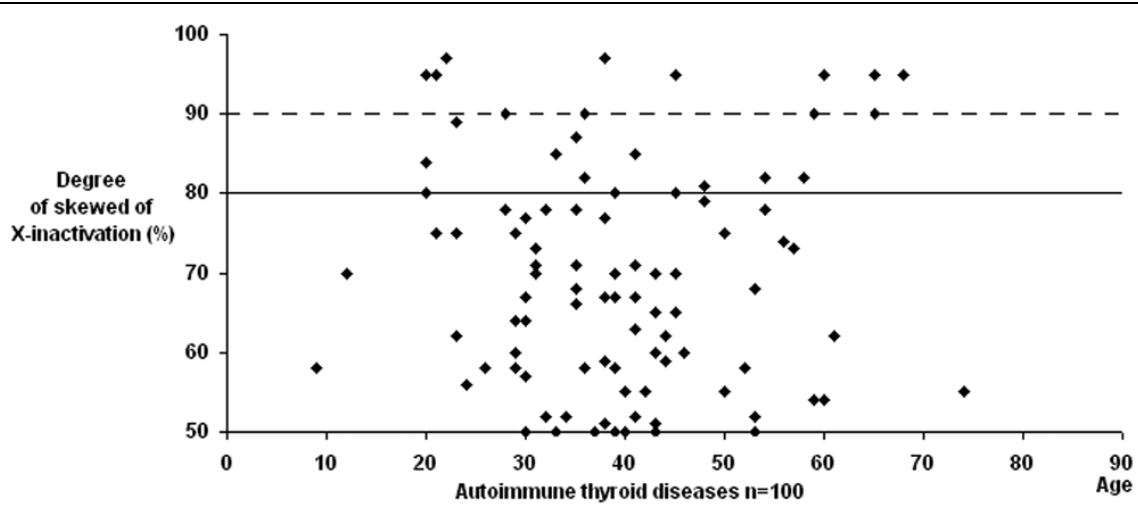

Distribution of X-chromosome inactivation patterns according to age in patients with autoimmune thyroid diseases. 


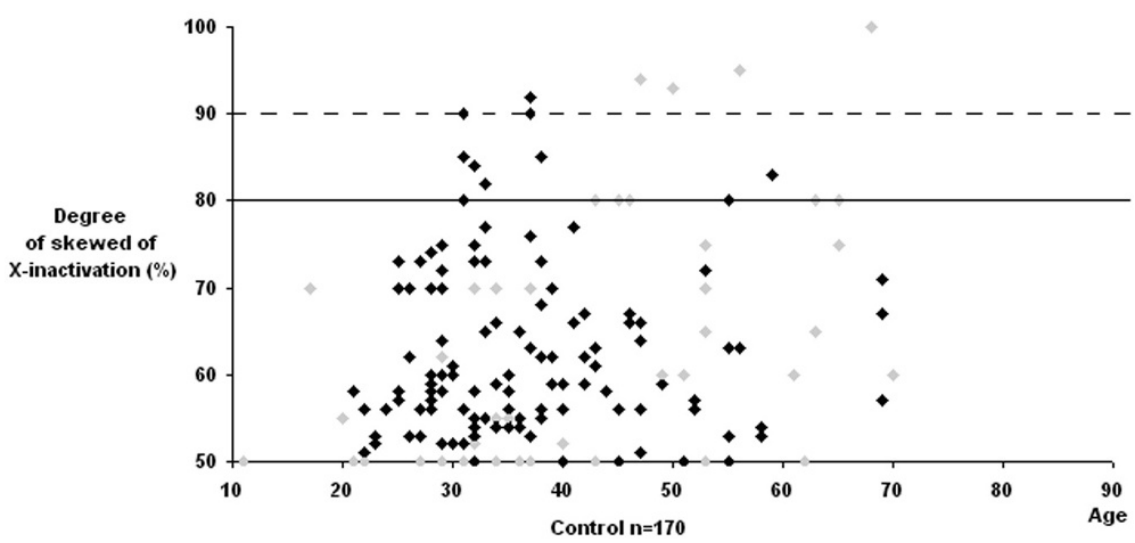

Distribution of X-chromosome inactivation patterns according to age control subjects. The control subjects were plotted according to geographic origin. Gray diamonds represent Tunisian controls and black diamonds represent Turkish controls.

less than one, or more than $20 \%$ of the cells had an expected count of less than five. $P$ values of 0.05 or less were considerate to be significant. Significance of $P$ value was assessed using a Bonferroni correction at $5 \%$ (a $P$ value less $0.05 / 9=$ 0.005 ) is considered significant.

\section{Results}

$\mathrm{XCl}$ status was found to be informative in 76 of the $106 \mathrm{RA}$ patients, 100 of the 145 AITDs patients and 170 of the 257 controls. Only those individuals whose alleles resolve adequately for densitometric analysis were included in the study. Skewed XCl (>80\% skewing) was observed in 26 of the 76 RA patients (34.2\%), 26 of the 100 AITDs patients (26\%), and 19 of the 170 controls $(11.2 \% ; P<0.0001$ and $P=0.0015)$. More importantly, the frequency of extremely skewed $\mathrm{XCl}(>$ $90 \%$ skewing) was $22.4 \%$ (17 of 76 ) in RA and $14.0 \%$ (14 of $100)$ in AITDs. These frequencies are both significantly higher than that of the control population, which is $4.1 \%$ (7 of $170 ; P$ $<0.0001$ and $P=0.0034$; Table 1). Subdividing AITDs patients according to clinical phenotype revealed that the frequency of skewed $\mathrm{XCl}$ was $35 \%$ (14 of $40, P=0.0001$ ) and $20 \%$ (12 of $60, P=0.04$ ) in GD and HT, respectively. Conversely, stratifying RA patients according to RF status, ACPA status, clinical manifestations (erosive disease and nodules) and others autoimmune diseases did not reveal a statistically significant difference $(P>0.05)$. Additionally, the comparison according to geographic origin showed a skewed $\mathrm{XCl}$ of RA patients compared with Tunisian controls (34.2\% versus $19.5 \% ; P=0.03)$. However, difference was non-significant for AITDs subgroup $(P>0.05)$.

Extremely skewed XCl have been reported in 1 to $2 \%$ of 20 to 40 year old women, and in 2 to $4 \%$ of 55 to 72 year old women [19]. The data for RA and AITDs patients is strikingly bimodal, we plotted the distribution of the $\mathrm{X}$ inactivation profiles according to age. However, we did not observe a shift toward the skewed range in older patients and controls (Figures 1,2 and
3). Characteristics of the RA and AITDs patients with skewed $\mathrm{XCl}$ are shown in Tables 2 and 3.

At the time of sample collection, 66 patients affected with RA were being treated with immunosuppressive therapies (methotrexate 10 to $15 \mathrm{mg}$ once a week, $\mathrm{n}=33$; D-penicillamine $300 \mathrm{mg} /$ day, $\mathrm{n}=17$; plaquenil 400 to $600 \mathrm{mg} /$ day, $\mathrm{n}=16$ ). Among 76 informative patients, 46 were received immunosuppressive agents (61\%). A major concern with the observed $\mathrm{XCl}$ patterns among RA patients was that concomitant immunosuppressive therapy could influence the results, as has been observed in feline hematopoietic cells [20]. Analysis of the data on $\mathrm{XCl}$ patterns according to immunosuppressive therapy did not reveal a statistically significant association between RA patients treated with methotrexate and controls $(P=0.52)$.

\section{Discussion}

The majority of human autoimmune diseases are characterized by female predominance. RA and AITDs have a female:male ratio of approximately $3: 1$ and $9: 1$, respectively [21]. Sex hormone influences have been suggested to explain this phenomenon because the $\mathrm{X}$-chromosome contains a considerable number of sex and immune-related genes such as $A R$, IL2 receptor gamma chain, CD4O ligand and FOXP3 [22,23]. These genes are essential in determining sex hormone levels and, more importantly, immune tolerance [24]. The contribution of genetics to sex differences in autoimmune diseases is currently unexplored. An alternative explanation for the female predominance has been recently proposed with the finding of an enhanced skewed $\mathrm{XCl}$ in peripheral bloods cells of female patients with autoimmune diseases [11-14]. The present study tests the hypothesis that skewed $\mathrm{XCl}$ would be more prevalent in females affected with autoimmune diseases than in female control individuals. Therefore, we simultaneously examined skewed $\mathrm{XCl}$ in 106 patients affected with $\mathrm{RA}$ and 145 patients affected with AITDs. The control group consisted 
Table 2

\begin{tabular}{|c|c|c|c|c|c|c|c|}
\hline Patient & Birth date & Disease onset & Pregnancy history & RF status & ACPA status & $\begin{array}{c}\text { Other autoimmune } \\
\text { disease }\end{array}$ & $\begin{array}{c}\text { immunosuppressive } \\
\text { therapy }\end{array}$ \\
\hline \multicolumn{8}{|c|}{$90+\%$ skewing } \\
\hline 1 & 1949 & 48 & $\mathrm{G} 7, \mathrm{P} 4, \mathrm{~A} 3$ & + & + & GSG & MXT \\
\hline 2 & 1954 & 42 & $\mathrm{G} 5, \mathrm{P} 4, \mathrm{~A} 1$ & + & + & - & Plaquenil \\
\hline 3 & 1945 & 52 & $\mathrm{G} 7, \mathrm{P} 7, \mathrm{AO}$ & - & - & GSG & - \\
\hline 4 & 1946 & 40 & $\mathrm{G} 3, \mathrm{P} 2, \mathrm{~A} 1$ & + & - & - & - \\
\hline 5 & 1956 & 30 & $\mathrm{G} 2, \mathrm{P} 2, \mathrm{AO}$ & - & - & - & - \\
\hline 6 & 1946 & 40 & $\mathrm{G} 3, \mathrm{P} 2, \mathrm{~A} 1$ & - & + & GSG & - \\
\hline 7 & 1945 & 40 & $\mathrm{G} 4, \mathrm{P} 4, \mathrm{AO}$ & + & - & - & - \\
\hline 8 & 1945 & 39 & $\mathrm{G} 5, \mathrm{P} 5, \mathrm{A0}$ & - & + & - & - \\
\hline 9 & 1941 & 49 & $\mathrm{G} 7, \mathrm{P} 5, \mathrm{~A} 2$ & + & + & - & MXT \\
\hline 10 & 1947 & 49 & $\mathrm{G} 4, \mathrm{P} 3, \mathrm{~A} 1$ & + & - & GSG & - \\
\hline 11 & 1945 & 58 & $\mathrm{G} 4, \mathrm{P} 2, \mathrm{~A} 1$ & - & + & GSG & MXT \\
\hline 12 & 1950 & 40 & $\mathrm{G} 3, \mathrm{P} 2, \mathrm{~A} 1$ & + & + & GSG & MXT \\
\hline 13 & 1943 & 53 & $\mathrm{G} 3, \mathrm{P} 3, \mathrm{AO}$ & + & - & - & - \\
\hline 14 & 1961 & 35 & $\mathrm{G} 2, \mathrm{P} 1, \mathrm{~A} 1$ & + & - & - & - \\
\hline 15 & 1937 & 38 & $\mathrm{G} 4, \mathrm{P} 4, \mathrm{AO}$ & - & - & - & - \\
\hline 16 & 1941 & 45 & $\mathrm{G} 5, \mathrm{P} 3, \mathrm{~A} 1$ & + & + & - & - \\
\hline 17 & 1947 & 43 & $\mathrm{G} 3, \mathrm{P} 2, \mathrm{AO}$ & - & + & GSG & - \\
\hline \multicolumn{8}{|c|}{80 to $89 \%$ skewing } \\
\hline 18 & 1959 & 42 & $\mathrm{G} 5, \mathrm{P} 5, \mathrm{A0}$ & + & + & - & MXT \\
\hline 19 & 1940 & 62 & $\mathrm{GO}, \mathrm{PO}, \mathrm{AO}$ & - & - & - & - \\
\hline 20 & 1938 & 60 & $\mathrm{G} 9, \mathrm{P} 8, \mathrm{~A} 1$ & + & + & GSG & MXT \\
\hline 21 & 1954 & 27 & $\mathrm{GO}, \mathrm{PO}, \mathrm{AO}$ & + & + & GSG & - \\
\hline 22 & 1957 & 37 & $\mathrm{G} 5, \mathrm{P} 5, \mathrm{A0}$ & + & + & GSG & - \\
\hline 23 & 1948 & 55 & $\mathrm{G} 9, \mathrm{P} 7, \mathrm{A0}$ & + & - & - & MXT \\
\hline 24 & 1948 & 55 & $\mathrm{GO}, \mathrm{PO}, \mathrm{AO}$ & - & - & - & - \\
\hline 25 & 1937 & 50 & $\mathrm{G} 3, \mathrm{P} 2, \mathrm{~A} 1$ & - & + & GSG & - \\
\hline 26 & 1985 & 14 & $\mathrm{GO}, \mathrm{PO}, \mathrm{AO}$ & + & - & - & - \\
\hline
\end{tabular}

A = spontaneous abortions; ACPA = anti-citrullinated protein/peptide antibodies; $\mathrm{G}=$ number of pregnancies; GSG = Sjögren's syndrome; MTX $=$ methotrexate; $\mathrm{P}=$ para (pregnancies carried to term and delivered); $R F=$ rheumatoid factor.

of 170 female age-matched healthy individuals. We have demonstrated a significantly higher prevalence of extremely skewed $\mathrm{XCl}$ in blood cell of females affected with RA and AITDs compared with the control group $(P<0.0001 ; P=$ 0.0015 , respectively), indicating a possible role of $\mathrm{XCl}$ in the etiology of autoimmune diseases, and in the female preponderance of RA and AITDs.

Skewed $\mathrm{XCl}$ was more commonly expected in peripheral blood mononuclear cells due to the very high rate of turnover of blood cells compared with other solid tissues [25]. Then, we have examined $\mathrm{XCl}$ in peripheral blood mononuclear cells of patients affected with RA and AITDs, and we found a higher incidence of skewed $\mathrm{XCl}$ in those patients. We also tested the relationship between $\mathrm{XCl}$ and AITDs phenotypes (GD and $\mathrm{HT}$ ). A skewed $\mathrm{XCl}$ was associated with both $\mathrm{GD}$ and $\mathrm{HT}(P$ $=0.0001$ and $P=0.04$ ). Although, our results suggest the involvement of $\mathrm{XCl}$ in female predisposition to RA and AITDs, this hypothesis still to be confirmed in specific tissue, because our analysis was performed in DNA from blood, and this may 
Table 3

\begin{tabular}{|c|c|c|c|c|c|}
\hline Patient & Birth date & Disease onset & Pregnancy history & Diagnostic & Auto antibodies \\
\hline \multicolumn{6}{|c|}{$90+\%$ skewing } \\
\hline 1 & 1978 & 22 & $\mathrm{G} 1, \mathrm{P} 1, \mathrm{A0}$ & $\mathrm{HT}$ & + \\
\hline 2 & 1933 & 65 & $\mathrm{G} 11, \mathrm{P} 5, \mathrm{A0}$ & HT & + \\
\hline 3 & 1969 & 20 & $\mathrm{G} 1, \mathrm{P} 1, \mathrm{~A} 1$ & $\mathrm{HT}$ & + \\
\hline 4 & 1938 & 60 & $\mathrm{G} 3, \mathrm{P} 3, \mathrm{AO}$ & GD & + \\
\hline 5 & 1943 & 45 & $\mathrm{G} 2, \mathrm{P} 2, \mathrm{AO}$ & GD & + \\
\hline 6 & 1972 & 21 & $\mathrm{G} 2, \mathrm{P} 2, \mathrm{AO}$ & HT & + \\
\hline 7 & 1964 & 36 & $\mathrm{G} 2, \mathrm{P} 2, \mathrm{AO}$ & HT & + \\
\hline 8 & 1924 & 65 & $\mathrm{G} 9, \mathrm{P9}, \mathrm{AO}$ & HT & + \\
\hline 9 & 1940 & 59 & $\mathrm{G} 10, \mathrm{P} 10, \mathrm{~A} 0$ & $\mathrm{HT}$ & + \\
\hline 10 & 1969 & 28 & $\mathrm{G} 4, \mathrm{P} 4, \mathrm{AO}$ & GD & + \\
\hline 11 & 1979 & 20 & $\mathrm{GO}, \mathrm{PO}, \mathrm{AO}$ & GD & - \\
\hline 12 & 1931 & 68 & $\mathrm{G} 13, \mathrm{P} 13, \mathrm{~A} 0$ & $\mathrm{HT}$ & - \\
\hline 13 & 1943 & 59 & $\mathrm{G} 1, \mathrm{P} 1, \mathrm{A0}$ & GD & - \\
\hline 14 & 1946 & 42 & $\mathrm{G} 2, \mathrm{P} 2, \mathrm{AO}$ & GD & - \\
\hline \multicolumn{6}{|c|}{80 to $89 \%$ skewing } \\
\hline 15 & 1969 & 23 & $\mathrm{G} 2, \mathrm{P} 2, \mathrm{AO}$ & $\mathrm{HT}$ & + \\
\hline 16 & 1950 & 41 & $\mathrm{G} 3, \mathrm{P} 2, \mathrm{~A} 1$ & GD & + \\
\hline 17 & 1980 & 20 & $\mathrm{GO}, \mathrm{PO}, \mathrm{AO}$ & $\mathrm{HT}$ & + \\
\hline 18 & 1945 & 54 & $\mathrm{G} 4, \mathrm{P} 3, \mathrm{AO}$ & $\mathrm{HT}$ & + \\
\hline 19 & 1962 & 36 & $\mathrm{G} 7, \mathrm{P} 2, \mathrm{~A} 5$ & $\mathrm{HT}$ & + \\
\hline 20 & 1954 & 48 & $\mathrm{G} 3, \mathrm{P} 3, \mathrm{AO}$ & GD & + \\
\hline 21 & 1984 & 20 & $\mathrm{GO}, \mathrm{PO}, \mathrm{AO}$ & GD & + \\
\hline 22 & 1952 & 45 & $\mathrm{G} 2, \mathrm{P} 2, \mathrm{AO}$ & GD & - \\
\hline 23 & 1941 & 58 & $\mathrm{G} 5, \mathrm{P} 5, \mathrm{A0}$ & $\mathrm{HT}$ & - \\
\hline 24 & 1953 & 39 & $\mathrm{G} 2, \mathrm{P} 2, \mathrm{AO}$ & GD & - \\
\hline 25 & 1947 & 48 & $\mathrm{G} 1, \mathrm{P} 1, \mathrm{AO}$ & $\mathrm{HT}$ & - \\
\hline 26 & 1969 & 43 & $\mathrm{G} 2, \mathrm{P} 1, \mathrm{~A} 1$ & GD & - \\
\hline
\end{tabular}

$A=$ spontaneous abortions; $G=$ number of pregnancies; $G D=$ Graves' disease; $H T=$ Hashimoto's thyroiditis; $P=$ para (pregnancies carried to term and delivered).

not be a representative tissue for all autoimmune diseases $[26,27]$ and there may exist locally skewed $\mathrm{XCl}$ in the thymus. Moreover, this study can be complicated by existing differences in peripheral blood mononuclear cells constituents in $\mathrm{RA}$ versus healthy controls. The $\mathrm{XCl}$ distribution in both Tunisian and Turkish controls (Figure 3 ) according to age showed that $19.5 \%$ (9 of 46 ) have a skewed $\mathrm{XCl}$ in Tunisian controls which have a mean age of 43.5 years, whereas only $8 \%$ (10 of $124)$ in Turkish controls with a younger mean age (35 years).
This result suggests the importance of age in the difference of $\mathrm{XCl}$ skewing.

Our results are in agreement with those reported by Ozçelik and colleagues on 110 unrelated Turkish female AITDs patients and 160 female controls that showed a greater proportion of a skewed pattern of $\mathrm{XCl}(34 \%)$ than in controls $(8 \%$; $P<0.0001$ ) [13]. Indeed, supporting data have been reported by Brix and colleagues, which assessed that the prevalence of skewed XCl in female twins affected with AITDs was 34\% but 
only $11 \%$ in controls $(P=0.003)$ and by $Y$ in and colleagues $(P=0.004)$ [12-14]. Similar positive result was described in other autoimmune diseases such as scleroderma [11]. In addition, our results are the first report that describes a significant association between extremely skewed $\mathrm{XCl}$ and $\mathrm{RA}$. Conversely, examination of $\mathrm{XCl}$ pattern of 58 Caucasian female patients affected with multiple sclerosis, 46 with systemic lupus erythematosus, 18 with juvenile RA and 45 with type 1 diabetes mellitus and 30 healthy women did not reveal skewed $\mathrm{XCl}$ patterns [28]. Despite extensive efforts of $\mathrm{XCl}$ analysis in different autoimmune diseases and populations, this hypothesis remains to be confirmed because there is no apparent autoimmunity directed against protein antigens encoded on the $\mathrm{X}$ chromosome and the fact that, for many autoimmune diseases, we found a female predominance in inbred mice models having two identical $\mathrm{X}$ chromosomes and therefore no 'foreign' antigens from the $\mathrm{XCl}$ [29].

In humans, it was reported that $\mathrm{XCl}$ process was genetically controlled by genes located on $X$ chromosome [30]. It has also been suggested that genes on the $X$ chromosome might show linkage with AITD and RA [31,32]. Thus, the observed association between skewed XCl and AITD and RA is not causal but could be explained by linkage disequilibrium between mutation responsible for $\mathrm{XCl}$ process and AITD and RA susceptibility polymorphisms. In addition, numerous environmental risk factors such as tobacco smoking, hormones, diet, drugs, toxins and/or infections are important in determining whether an individual will develop autoimmune diseases [33]. In fact, environmental agents are able to amplify autoimmunity in genetically susceptible individuals and to break tolerance in genetically resistant individuals, there by increasing the risk of developing autoimmune diseases [34]. The interaction between genetic and environmental factors remains to be achieved in order to evaluate the involvement of each component in the development of such autoimmune reactions.

\section{Conclusions}

We suggest a possible role of $\mathrm{XCl}$ mosaicism in the pathogenesis of RA and AITDs. However, the process of XCl needs to be considered as a potential factor in the predominance of females in most autoimmune diseases. It would also be of interest first to study the $\mathrm{XCl}$ pattern in females affected with other autoimmune diseases and second to test the $\mathrm{XCl}$ patterns of many cell types.

\section{Competing interests}

The authors declare that they have no competing interests.

\section{Authors' contributions}

GC carried out the molecular genetic study, performed the statistical analysis and wrote the manuscript. EU participated in the experimental work and the statistical analysis. AM participated in the design of the study and helped to draft the manuscript. AR participated in the statistical analysis. MM made pathological diagnosis and performed clinical data analyses. CAM participated in the molecular genetic study. ZB made pathological diagnosis, conducted sampling procedures, and performed clinical and rheumatological data analyses. TO conceived of the study, and participated in its design and coordination and helped to draft the manuscript. HA participated in the coordination of the study and revised the manuscript. All authors read and approved the final manuscript.

\section{Acknowledgements}

This work was funded by Ministère de l'Enseignement Supérieur, Ministère de la Recherche Scientifique et de la Technologie (Tunisie). The International Centre for Genetic Engineering and Biotechnology ICGEB-CRP/TUR04-01, and Scientific and Technical Research Council of Turkey-TUBITAK-SBAG 3334 (to Dr. Ozcelik).

\section{References}

1. Rougeulle $\mathrm{C}$, Avner $\mathrm{P}$ : Controlling $\mathbf{X}$-inactivation in mammals: what does the centre hold? Semin Cell Dev Biol 2003, 14:331-340.

2. Kast RE: Predominance of autoimmune and rheumatic diseases in females. J Rheumatol 1977, 4:288-292.

3. Stewart JJ: The female $x$ inactivation mosaic in systemic lupus erythematosus. Immunol Today 1998, 19:352-257.

4. Klein L, Klugmann M, Nave K-A, Tuohy VK, Kyewski B: Shaping of the autoreactive T-cell repertoire by a splice variant of self protein expressed in thymic epithelial cells. Nature Med 2000, 6:56-61.

5. Puck JM, Stewart CC, Nussbaum RL: Maximum likelihood analysis of human T-cell X-chromosome inactivation patterns: normal women versus carriers of $X$-linked severe combined immunodeficiency. Am J Hum Genet 1992, 50:742-748.

6. Kristiansen M, Knudsen GPS, Bathum L, Naumova AK, Sorensen TI, Brix TH, Svendsen AJ, Christensen K, Kyvik KO, Orstavik KH: Twin study of genetic and aging effects on X-chromosome inactivation. Eur J Hum Genet 2005, 13:599-606.

7. Sharp A, Robinson D, Jacobs P: Age- and tissue-specific variation of $\mathrm{X}$-chromosome inactivation ratios in normal women. Hum Genet 2000, 107:343-349.

8. Belmont JW: Genetic control of $\mathbf{X}$ inactivation and processes leading to X-inactivation skewing. Am J Hum Genet. 1996, 58:1101-1108.

9. Laufer TM, Dekoning J, Markowitz JS, Lo D, Glimcher LH: Unopposed positive selection and autoreactivity in mice expressing class II MHC only on thymic cortex. Nature 1996, 383:81-85.

10. Kyewski B, Derbinski J: Self-representation in the thymus: anextended view. Nat Rev Immunol 2004, 4:688-698.

11. Ozbalkan Z, Bagislar S, Kiraz S, Akyerli CB, Ozer HT, Yavuz S, Birlik AM, Calguneri M, Ozcelik T: Skewed X-chromosome inactivation in blood cells of women with scleroderma. Arthritis Rheum 2005, 52:1564-1570.

12. Brix TH, Knudsen GP, Kristiansen $M$, Kyvik $K$, Orstavik KH, Hegedus L: High frequency of skewed $X$-chromosome inactivation in females with autoimmune thyroid disease: a possible explanation for the female predisposition to thyroid autoimmunity. J Clin Endocrinol Metab 2005, 90:5949-5953.

13. Ozcelik T, Uz E, Akyerli CB, Bagislar S, Mustafa CA, Gursoy A, Akarsu N, Toruner G, Kamel N, Gullu S: Evidence from autoimmune thyroiditis of skewed $\mathrm{X}$-chromosome inactivation in female predisposition to autoimmunity. Eur J Hum Genet 2006, 14:791-797.

14. Yin $X$, Latif $R$, Tomer $Y$, Davies TF: Thyroid epigenetics: $x$-chromosome inactivation in patients with autoimmune thyroid disease. Ann N Y Acad Sci 2007, 1110:193-200.

15. Arnett FC, Edworthy SM, Bloch DA, McShane DJ, Fries JF, Cooper NS, Healey LA, Kaplan SR, Liang MH, Luthra HS: The American Rheumatism Association 1987 revised criteria for the classification of rheumatoid arthritis. Arthritis Rheum 1988, 31:315-324.

16. Kawazaki E: Sample preparation from blood, cells and other fluids. In Origin of PCR protocols. A guide to methods and appli- 
cation Edited by: Innis M, Gelffand D, Snisky G, White T. San Diego: Academic Press; 1990:146-152.

17. Allen RC, Zoghbi HY, Moseley AB, Rosenblatt HM, Belmont JW: Methylation of Hpall and Hhal sites near the polymorphic CAG repeat in the human androgen-receptor gene correlates with X-chromosome inactivation. Am J Hum Genet 1992, 51:1229-1239.

18. Delforge $M$, Demuynck $H$, Vandenberghe $P$, Verhoef $G$, Zachée $P$, van Duppen V, Marijnen P, Berghe H Van den, Boogaerts MA: Polyclonal primitive hematopoietic progenitors can be detected in mobilized peripheral blood from patients with high-risk myelodysplastic syndromes. Blood 1995, 86:3660-3667.

19. Knudsen GP, Pedersen J, Klingenberg O, Lygren I, Ãrstavik KH: Increased skewing of $X$-chromosome inactivation with age in both blood and buccal cells. Cytogenet Genome Res 2007, 116:24-28.

20. Abkowitz JL, Linenberger ML, Persik M, Newton MA, Guttorp P: Behavior of feline hematopoietic stem cells years after busulfan exposure. Blood 1993, 82:2096-2103.

21. Lockshin MD: Sex differences in autoimmune disease. Lupus 2006, 15:753-756

22. Chagnon P, Provost S, Belisle C, Bolduc V, Gingras M, Busque L: Age-associated skewing of $X$-inactivation ratios of blood cells in normal females: a candidate-gene analysis approach. Exp Hematol 2005, 33:1209-1214.

23. Noguchi M, Yi H, Rosenblatt HM, Filipovich AH, Adelstein S, Modi WS, McBride OW, Leonard WJ: Interleukin-2 receptor gamma chain mutation results in $\mathrm{X}$-linked severe combined immunodeficiency in humans. Cell 1993, 73:147-157.

24. HernAindez-Molina G, Svyryd Y, SÃinchez-Guerrero J, Mutchinick $\mathrm{OM}$ : The role of the $\mathrm{X}$-chromosome in immunity and autoimmunity. Autoimmun Rev 2007, 6:218-222.

25. Sharp A, Robinson D, Jacobs P: Age- and tissue-specific variation of X-chromosome inactivation ratios in normal women. Hum Genet 2000, 107:343-349.

26. Azofeifa J, Waldherr R, Cremer M: X-chromosome methylation ratios as indicators of chromosomal activity: evidence of intraindividual divergencies among tissues of different embryonal origin. Hum Genet 1996, 97:330-333.

27. Gale RE, Wheadon H, Boulos $P$, Linch DC: Tissue specificity of X-chromosome inactivation patterns. Blood 1994, 83:2899-2905

28. Chitnis S, Monteiro J Glass D, Apatoff B, Salmon J Concannon P, Gregersen PK: The role of X-chromosome inactivation in female predisposition to autoimmunity. Arthritis Res 2000, 2:399-406.

29. Smith-Bouvier DL, Divekar AA, Sasidhar M, Du S, Tiwari-Woodruff SK, King JK, Arnold AP, Singh RR, Voskuhl RR: A role for sex chromosome complement in the female bias in autoimmune disease. J Exp Med 2008, 12:1099-1108.

30. Naumova AK, Olien L, Bird LM, Smith M, Verner AE, Leppert M, Morgan K, Sapienza C: Genetic mapping of X-linked loci involved in skewing of $X$ chromosome inactivation in the human. Eur J Hum Genet 1998, 6:552-562.

31. Tomer Y, Davies TF: Searching for the autoimmune thyroid disease susceptibility genes: from gene mapping to gene function. Endocr Rev 2003, 24:694-717.

32. Shiozawa S, Hayashi S, Tsukamoto Y, Goko H, Kawasaki H, Wada T, Shimizu K, Yasuda N, Kamatani N, Takasugi K, Tanaka Y, Shiozawa K, Imura S: Identification of the gene loci that predispose to rheumatoid arthritis. Int Immunol 1998, 10:1891-1895.

33. Edwards CJ, Cooper C: Early environmental factors and rheumatoid arthritis. Clin Exp Immunol 2005, 143:1-5.

34. Guarneri F, Benvenga S: Environmental factors and genetic background that interact to cause autoimmune thyroid disease. Curr Opin Endocrinol Diabetes Obes 2007, 14:398-409. 